\title{
Pedicled versus in situ internal thoracic artery: A petition for consistency in communication
}

\author{
Hadi Daood Toeg, MD, MSc, and Fraser Douglas Rubens, MD, MSc, FACS, FRCSC
}

\author{
"How often misused words generate misleading \\ thoughts." \\ -Herbert Spencer, Principles of Ethics, \\ Volume $1 ; 1879^{1}$
}

Clarity is the sine qua non of effective communication, and thus it is essential that journals advocate that clinical researchers consider appropriate and consistent descriptions in their submissions. It is in this context that this editorial aims to elucidate the use of the terms pedicled and in situ as they refer to harvest of the internal thoracic artery (ITA) in coronary artery bypass surgery ${ }^{2,3}$ to facilitate the sharing of clinical information in this field of cardiac surgery.

Pedicle, from the Latin word pediculus meaning small foot, is described in the Oxford English Dictionary as "a small stalk-like structure connecting an organ or other part to the human body" 4,5 In general, all medical dictionaries including Stedman's, Taber's, and Dorland's, present the consensus understanding that the term pedicle means, "a constricted portion or stalk, by which a nonsessile tumor is attached to normal tissue, or a stalk through which flap of tissue is vascularized, permitting transfer to another site," ${ }^{6-8}$ The anatomic definition with regard to the vertebral arch, in which the pedicle is the segment joining the transverse process and the vertebral body, is consistent with this definition.

In plastic surgery, the term pedicled flap refers to a tissue island that retains a donor site attachment. ${ }^{9,10}$ This is a flap that is transported to a new location while keeping the stalk intact with its original blood supply, ${ }^{11}$ such as with the pedicled transverse rectus abdominus muscle in breast reconstruction. ${ }^{12}$ Our plastic surgery colleagues subsequently popularized the concept of a free flap, which involved detaching the tissue and blood supply from its original location and transferring it to a new one, with microvascular techniques used to ensure viability. ${ }^{13}$ In summary, these

From the Division of Cardiac Surgery, University of Ottawa Heart Institute, Ottawa, Ontario, Canada.

Disclosures: Authors have nothing to disclose with regard to commercial support.

Received for publication Aug 25, 2013; accepted for publication Aug 30, 2013; available ahead of print Nov 4, 2013.

Address for reprints: Fraser Douglas Rubens, MD, MSc, FACS, FRCSC, Division of Cardiac Surgery, University of Ottawa Heart Institute, 40 Ruskin St, Ottawa,

Ontario, Canada (E-mail: frubens@ottawaheart.ca).

J Thorac Cardiovasc Surg 2014;147:4-5

0022-5223/\$36.00

Copyright (c) 2014 by The American Association for Thoracic Surgery

http://dx.doi.org/10.1016/j.jtcvs.2013.08.082 terms have been used in a clear manner in the reconstructive surgical literature, consistent with the original etymology.

The inconsistent and confusing use of the terms pedicle and in situ with respect to the preparation of the ITA have unnecessarily complicated the cardiac literature. A recent meta-analysis by Deo and colleagues ${ }^{14}$ perpetuates this misunderstanding by comparing outcomes of different harvesting or grafting techniques in coronary artery bypass grafting. Deo and colleagues ${ }^{14}$ describe that the pedicle group as consisting of those undergoing "conventional method for ITA harvest" and compare this group with those in whom skeletonization was performed. They concluded that "while BITA [bilateral ITA] was associated with increased risk of deep sternal wound infections compared to LITA [left ITA], this was limited to patients with a pedicled harvesting approach," implying that the adjective pedicled is the antonym to the adjective skeletonized. This particular definition of pedicled reflects that described by Sá and associates ${ }^{15-17}$ as a technique involving "dissect[ing] the artery away from the sternum with its accompanying veins, fascia, adipose tissue and lymphatics, generating a pedicled graft." Other groups have used this definition in their reports, including Kai and colleagues, ${ }^{18}$ who compared patency rates between off-pump skeletonized bilateral ITA grafting versus on-pump "pedicled" bilateral ITA grafting.

To clarify that grafts remained attached proximally to the subclavian artery (not free), these and other authors have used the Latin term in situ. The Oxford English Dictionary specifies that the term in situ may be used as an adjective or adverb, reflecting something "in its original place." Clearly, the transfer of the end of the vessel to an entirely different site for an anastomosis is not consistent with this definition.

We believe that the proper use of the term pedicled in the context of coronary grafting was first presented in this Journal by Kushwaha and coworkers. ${ }^{19}$ These authors highlighted the important potential physiologic relevance of the changes in vascular and nervous supply after dividing the proximal connecting stalk. Furthermore, in a large series of multiple arterial grafting the implied definition of pedicled related to the use of the ITA with its proximal connection intact, as opposed to a free graft, with no reference to the degree of skeletonization during harvesting. $^{20}$

We propose that our specialty journals encourage a simple and logical descriptive process involving 2 dichotomous variables relating to ITA preparation. First, the terms 
skeletonized and nonskeletonized appropriately reflect the degree of isolation of the artery from the surrounding tissue in the conduit. ${ }^{21,22}$ Second, when the proximal connection of the conduit to the subclavian artery is preserved, it is a pedicled graft, whereas when it is divided, it is a free graft. The term in situ should be reserved as a descriptor for situations in which the proximal and distal connections of the vessel are intact. For example, "the vessel was skeletonized in situ until the heparin was given, and then it was divided distally."

In summary, this editorial comprises a plea to consider the universal acceptance of 2 simple, reproducible dichotomous descriptions of ITA harvest and grafting. The ITA has proven extraordinary longevity and consistency as a conduit, and we owe it as practitioners to embrace descriptive terms as useful and consistent as the conduit itself.

I have labored to refine our language to grammatical purity, and to clear it from colloquial barbarisms, licentious idioms, and irregular combinations.

\section{-Samuel Johnson, The Rambler,} Section 208; $1752^{23}$

\section{References}

1. Spencer H. The Principles of Ethics. Vol. 1. 1897.

2. Gaudino M, Toesca A, Glieca F, Girola F, Luciani N, Possati G. Skeletonization does not influence internal thoracic artery innervation. Ann Thorac Surg. 2004; 77:1257-61.

3. Rubens FD, Boodhwani M. Skeletonization of the internal thoracic artery for coronary artery bypass grafting. Current Opin Cardiol. 2009;24:559-66.

4. Simpson JA, Weiner ESC; Oxford University Press. The Oxford English Dictionary. 2nd ed. Oxford: Oxford University Press; 1989.

5. Stevenson A, Lindberg CA. New Oxford American Dictionary. 3rd ed. Oxford: Oxford University Press; 2010.

6. Dorland WA. Dorland's Illustrated Medical Dictionary. Philadelphia: WB Saunders; 1957.

7. Taber CW, Thomas CL. Taber's Cyclopedic Medical Dictionary. 18th ed. Philadelphia: F.A. Davis; 1977

8. Stedman TL. Stedman's Medical Dictionary. 28th ed. Philadelphia: Lippincott Williams \& Wilkins; 2006.
9. Zhao JC, Xian CJ, Yu JA, Shi K. Pedicled full-thickness abdominal flap combined with skin grafting for the reconstruction of anterior chest wall defect following major electrical burn. Int Wound J. Epub 2013 Mar 13.

10. Iwamoto Y, Kanda H, Tsujii M, Toiyama Y, Yamada Y, Soga N, et al. Pedicled vastus lateralis musculofascial flap as a new technique for repairing rectourethral fistula after radical prostatectomy. Microsurgery. 2011:31:564-7.

11. Tehrani H, Srinivasan JR. The pectoralis minor pedicled muscle flap in axillary reconstruction. Ann Plast Surg. 2009;62:405-6.

12. Clugston PA, Gingrass MK, Azurin D, Fisher J, Maxwell GP. Ipsilatera pedicled TRAM flaps: the safer alternative? Plast Reconstr Surg. 2000;105: 77-82.

13. Karanas YL, Santoro TD, Da Lio AL, Shaw WW. Free TRAM flap breast reconstruction after abdominal liposuction. Plast Reconstr Surg. 2003;112: 1851-4

14. Deo SV, Shah IK, Dunlay SM, Erwin PJ, Locker C, Altarabsheh SE, et al Bilateral internal thoracic artery harvest and deep sternal wound infection in diabetic patients. Ann Thorac Surg. 2013;95:862-9.

15. Sá MP, Ferraz PE, Escobar RR, Vasconcelos FP, Ferraz AA, Braile DM, et al Skeletonized versus pedicled internal thoracic artery and risk of sternal wound infection after coronary bypass surgery: meta-analysis and meta-regression of 4817 patients. Interact Cardiovasc Thorac Surg. 2013;16:849-57.

16. Sá MP, Soares EF, Santos CA, Figueiredo OJ, Lima RO, Escobar RR, et al Risk factors for mediastinitis after coronary artery bypass grafting surgery. Rev Bras Cir Cardiovasc. 2011:26:27-35

17. Sá MP, Soares EF, Santos CA, Figueiredo OJ, Lima RO, Escobar RR et al. Skeletonized left internal thoracic artery is associated with lower rates of mediastinitis in diabetic patients. Rev Bras Cir Cardiovasc 2011;26:183-9.

18. Kai M, Hanyu M, Soga Y, Nomoto T, Nakano J, Matsuo T, et al. Off-pump coronary artery bypass grafting with skeletonized bilateral internal thoracic arteries in insulin-dependent diabetics. Ann Thorac Surg. 2007;84:32-6. English, Portuguese.

19. Kushwaha SS, Bustami M, Tadjkarimi S, Ilsley CD, Mitchell AG, Yacoub MH Late endothelial function of free and pedicled internal mammary artery grafts J Thorac Cardiovasc Surg. 1995;110:453-62

20. Tavilla G, Kappetein AP, Braun J, Gopie J, Tjien AT, Dion RA. Long-term follow-up of coronary artery bypass grafting in three-vessel disease using exclusively pedicled bilateral internal thoracic and right gastroepiploic arteries. Ann Thorac Surg. 2004;77:794-9; discussion 799.

21. Boodhwani M, Nathan HJ, Lam BK, Rubens FD. The internal thoracic artery skeletonization study: a paired, within-patient comparison [NCT00265499] Trials. 2006;7:1.

22. Boodhwani M, Lam BK, Nathan HJ, Mesana TG, Ruel M, Zeng W, et al. Skeletonized internal thoracic artery harvest reduces pain and dysesthesia and improves sternal perfusion after coronary artery bypass surgery: a randomized, double-blind, within-patient comparison. Circulation. 2006;114 766-73

23. Johnson S. The Rambler. Sections 171-208 (1751-1752). 1754. 